\title{
Effects of Blended Fertilizer (Nitrogen, Phosphorus, Sulfur and Boron) Rates on Yield, Yield Components and Grain Quality of Crop, (Durum Wheat)
}

\section{Melaku Tafese Awulachew*}

Department of Food Science and Nutrition Research Process, Ethiopian Institute of Agricultural Research, Kulumsa Agricultural Research Center Assela, Ethiopia

*Corresponding Author: Melaku Tafese Awulachew, Department of Food Science and Nutrition Research Process, Ethiopian Institute of Agricultural Research, Kulumsa Agricultural Research Center Assela, Ethiopia.

Received: October 10, 2019; Published: October 21, 2019

DOI: 10.31080/ASAG.2019.03.0691

\section{Abstract}

The objective of this review was design to pay attention to guide to determine the effect of blended fertilizer (NPSB) rates on yield related traits, yield and grain quality of durum wheat. Use of appropriate varieties and balanced fertilizer recommendation are important agronomic practices used to increase the productivity and quality of durum wheat. Hence, field experiment was carried out to assess the effect of NPSB blended fertilizer rates on yield, yield related traits and end-use quality of selected durum wheat cultivars. Moreover, the response of wheat to application of fertilizer varies with varieties, rainfall, soils, agronomic practices etc. Thus, there is a need to develop location specific recommendation on the fertilizer rates to increase the productivity and quality of especially recently released varieties.

Keywords: Fertilizer Rates; Grain Quality of Wheat; Yield; Yield Components

\section{Introduction}

Wheat (Triticum spp L.) is the most widely grown crop in the world with its unique protein characteristics that serves as an important source of food and energy [1]. Wheat is one of the major cereal crops grown in the highlands of Ethiopia and this region is regarded as the largest wheat producer in Sub-Saharan Africa [2]. It is mainly grown in the highlands of Ethiopia, which lie between 6 and $16^{\circ} \mathrm{N}$ latitude, and 35 and $42^{\circ} \mathrm{E}$ longitude, at altitudes ranging from 1500 to 2800 meters above sea level. Besides, wheat is produced across a wide range of soil conditions, although it is best adapted to fertile, well-drained silt and clay loam soils. The ideal daily temperature for wheat is between $16-25^{\circ} \mathrm{C}$ for proper plant development. The crop can be grown in most locations where annual rainfall ranges from 250-1750 mm.

Wheat is cultivated in Ethiopia about 1.69 million hectares and contributing about 4.5 million tons of grain yields, accounting for 13.5 percent of total grain output in the country [3]. There are two types of wheat grown in Ethiopia: durum wheat, accounting for 40 percent of production, and bread wheat, accounting for the remaining 60 percent.

Durum wheat (Triticum turgidum var. durum) is one of the most important food crops in the world, cultivated on about 20 million hectares [4]. In Ethiopia, durum wheat is predominantly grown in Central, Southeastern, Northwestern and Northeastern parts of Ethiopia, ranging from 1800-2800 meters above sea level. It is used to prepare a variety of local food recipes [5]. Moreover, it is mainly used to make semolina for macaroni, spaghetti and other pasta products. Ethiopia is endowed with huge amounts of genetic variation for durum wheat, and is recognized as the center of diversity.

Due to various reasons, locally produced durum wheat grains are censured to be poor quality and do not meet the minimum quality standard of pasta production. Some of the factors contributing to lower yield and quality of durum wheat are poor fertilizer application, weeds, diseases and pest, moisture stress, water lodging, land degradation, lack of disease resistance and high yielding varieties and low soil fertility conditions and poor grain management practices. The major soil-related causes for low crop productivity in Ethiopia are land degradation, severe nutrient depletion due to multiple factors, un balanced fertilizer use, low fertilizer use efficiency, soil acidity and soil salinity. Hence, in spite of the large volume of local production, some processing industries opt to import durum wheat grain for pasta production [5]. Therefore, it is basic to improve durum wheat productivity and grain quality to satisfy the demands of the processing industries, durum wheat producing farmers and consumers.

Quality has also become an important issue in variety choice, in particular, and it is being given more emphasis when marketing grains) [6]. The quality of du rum wheat is highly dependent on the protein content of the grain, which is largely dependent on 
genotypes and influenced by environment, especially nitrogen $(\mathrm{N})$ availability of the soil. Nitrogen fertilization management, therefore, offers the opportunity for increasing wheat protein content and other related quality traits. The protein content of grain is of high value for defining the end-use quality of both Triticum aestivum and T. durum grain [7]. Grain protein content is a function of total nitrogen uptake and of the partitioning of nitrogen and dry matter to the grain.

Nutrient mining due to sub optimal fertilizer use in one hand and unbalanced fertilizer uses on other have favored the emergence of multi nutrient deficiency in Ethiopian soils that in part have contributed to fertilizer factor productivity decline experienced over recent past. Different research reports indicate that nutrients like K, S, Ca, Mg and all micro-nutrients except Fe are becoming depleted and deficiency symptoms are being observed on major crops in different areas of the country [8].

The national soil inventory data also revealed that in addition to nitrogen and phosphorus, sulfur, boron and zinc deficiencies are widespread in Ethiopian soils, while some soils are also deficient in potassium, copper, manganese and iron which all potentially hold back crop productivity despite continued use of $\mathrm{N}$ and $\mathrm{P}$ fertilizers as per the blanket recommendation [9]. Future gains in food grain production will be more difficult and expensive to achieve considering the increasing problem of multi nutrient deficiencies.

Currently, with the emerging agro-industries using wheat as a raw material, good quality of durum wheat grain for processing has become increasingly important. There is a high demand by both commercial and small-scale peasant farmers for wheat cultivars with higher grain yield and better end-use quality. Moreover, there are several combinations of blended fertilizers developed by the Ethiopian Agricultural Transformation Agency for different agroecologies of the country. Different blended fertilizers are recommended in the country which includes some vital elements such as $\mathrm{N}, \mathrm{P}, \mathrm{S}, \mathrm{B}, \mathrm{K}, \mathrm{Z}, \mathrm{Cu}, \mathrm{Fe}$, etc. However, there is limited information on the impact of blended fertilizer application rate on yield, grain and flour quality aspect of durum wheat varieties grown in Ethiopia.

Therefore, different fertilizer materials would be required to ensure balanced fertilizer use involving all or most of the nutrients required by crops.

Several improved durum wheat varieties were developed and released for commercial production, through intensive evaluation and selection of natural variants of landraces and segregates of durum wheat lines. However, varietal development was mainly focused on grain yield, disregarding grain quality traits [10]. Moreover, the response of wheat to application of fertilizer varies with varieties, rainfall, soils, agronomic practices etc. Thus, there is a need to develop location specific recommendation on the fertilizer rates to increase the productivity and quality of especially recently released durum wheat varieties. Therefore, this overview was design to pay attention to guide to determine the effect of blended fertilizer (NPSB) rates on yield related traits, yield and grain quality of durum wheat.

\section{Literature Review}

Importance of durum wheat

Durum wheat, $2 \mathrm{n}=28$, genome AABB, is in the family Poaceae, tribe Triticeae. Among all cultivated wheats, Tritícum aestívum and Triticum turgidum L. var durum are the most important cereal crops in the world. It is the second most cultivated wheat species in the world next to common wheat [11]. Also it is better adapted to semiarid climates than is bread wheat. In recent years; wheat became one of the most important cereal crops in Ethiopia ranking 3rd in total grain production (17.02\%) next to tef [3].

Durum wheat is grown on only 8 to $10 \%$ of all the wheat cultivated area in the world. The remaining area is cultivated with hexaploid bread wheat [12]. In spite of its low acreage, durum wheat is an economically important crop because of its unique end product making characteristics. It is widely known to be the best type of wheat for pasta products because of its hardness, amber color and vitreous endosperm. It is generally known as the hardest kernel of all wheat classes. Wheat is grown in a wide range of environments that affect overall performance, particularly grain yield and enduse quality. Its yield and end-use quality depend upon the environment, genotype, and their interactions [13].

Durum wheat grain is used to prepare various products in different parts of the world. It is used predominantly for pasta and couscous but the use of durum wheat in flat and specialty breads is also common in Mediterranean countries, the Middle East, and North Africa. Traditionally, pasta is manufactured solely from durum wheat, which results in a product considered to be of superior quality to pasta made from cheaper common wheat or a blend of the two species [14]. In Ethiopia, it is consumed traditionally in the form of whole wheat, fermented and leavened local bread or as flat bread. Worldwide, durum wheat is milled into semolina, a raw material for pasta making and to prepare couscous (cooked grits) in Arab countries. It has traditionally been used for pasta products in the domestic American markets; although its use in baked goods is common in Southern Italy, the Middle East, and North Africa. Consequently, studies of bread-making quality of durum wheat have been reported by several authors, including $[15,16]$.

Most durum wheat cultivar development programs focus on improving pasta-making quality, but strategies to improve the breadmaking quality may also be worthwhile because such cultivars could be used either alone for bread production or in blends with bread wheat flour. In addition, durum wheat breads are higher in lutein, have longer shelf life, and a pleasant aroma [17]. Durum wheat varieties with both good pasta-making and bread-making quality would be an advantage to increase market demand. 
Effects of nitrogen on yield and yield related traits of durum wheat

The yield of wheat is a function of many factors, among them the cultivars and nitrogen fertilization being the most important ones. Grain yield is the most integrative character because it is influenced by all factors that determine productivity. Nitrogen is the most important plant nutrient needed to obtain high wheat yields. With fertilizers becoming important inputs to maximize crop yield and nitrogen fertilizer being determinant in wheat production in Ethiopia, several $\mathrm{N}$ fertilizer trials have been undertaken to determine the optimum levels for economically profitable yields. Results indicated that nitrogen rates had significant positive effect on yield up to $230 \mathrm{~kg} \mathrm{ha}^{-1}$. Most Ethiopian soils are deficit in nutrients, especially nitrogen and phosphorus and fertilizer application has significantly increased yields of crops [18].

Thus, there is quantitative relationship between crop yield and accumulation of $\mathrm{N}$ by plants, i.e. when the soil cannot supply with adequate $\mathrm{N}$, the crop yield will be constrained [19].This indicates that yield can be considered as a good measure of the collective impact of environment on plant growth, (i.e., the more favorable the environment, the more the effective $\mathrm{N}$ applied is and hence the greater the yield). Thus, properly applied nitrogen fertilization has a positive effect on crop yield. At a high level of such fertilization, it is advantageous to apply it twice or three times to plants at different stages of crop development [20].

Studies on N application on Nitisols at Holetta and Vertisols at Ginchi showed that application of $50 \%$ of the total nitrogen at sowing and the rest at full tillering stage significantly increased grain yield as well as the protein content of wheat [21]. Hence, nitrogenous fertilizers influence yield and grain protein percentage to varying degrees, depending on the rate of $\mathrm{N}$ application, on the level and form of soil $\mathrm{N}$ and on available water in the soil [22].

Yield and yield related traits of wheat are influenced by several factors of which nitrogen fertilization is the most important [23]. Application of nitrogen improves various yield related traits like 1000-grain weight, more productive tillers, more number of spikes per unit area, number of grains per spike and biological yield [24] thus resulting in higher yields. plant height, flag leaf area, and tillers number and dry weight per unit area of wheat were increased with increasing $\mathrm{N}$ rates up to $120 \mathrm{~kg} \mathrm{ha}^{-1}$ [25].

Application of different rates of nitrogen produced significantly positive impact on yield and yield related traits of wheat [26]. The entire yield related traits showed positive increase with the increased level of nitrogen applications. In their study, application of $140 \mathrm{~kg} \mathrm{~N} \mathrm{ha}^{-1}$ exhibited the highest performance among the treatments and statistically significant over the control.

A beneficial effect of nitrogen application on wheat was also reported by [27]. They noted that numbers of tillers and spikes per $\mathrm{m}^{2}$, plant height, spike length, number of spikelet and grains per spike, grain and straw yields of wheat increased with increasing $\mathrm{N}$ level. Nitrogen rates significantly influenced spike length and protein percentage too. In their experiment, increasing nitrogen rates from 70 to $110 \mathrm{~kg} \mathrm{~N} \mathrm{ha}^{-1}$ resulted in progressive increase in dry matter accumulation. The highest values were obtained at maximum nitrogen rate and the lowest ones at minimum nitrogen rate [27]. However, Briggs indicated that grain yield related traits of cereals vary widely with cultivar, soil fertility level and other growth limiting factors such as water stress and planting dates [28]. In general, yield and yield related traits of high yielding varieties increase with increasing levels of nitrogen [29].

An increase in straw yield with $\mathrm{N}$ application on cereals particularly wheat and barley, is well documented [30]. According to them, straw yield was increased with increasing $\mathrm{N}$ rate up to $160 \mathrm{~kg}$ ha-1 for winter wheat, but no effect on spring wheat which might be due to shorter growing period. In general, $\mathrm{N}$ application has increased straw yield of wheat, but the effect could vary with seasonal [31].

Several researchers in Ethiopia have reported that the role of $\mathrm{N}$ in wheat production in the highlands as substantial increases in yield and yield components have been affected with the application of $\mathrm{N}$ fertilizer [32]. Increasing levels of nitrogen increased grain and dry matter yields, number of kernels per head, number of tillers and plant height of wheat [33]. The nitrogen rates had significant effect on durum wheat yield and yield related traits such as: plant height, spike length, biomass yield, harvest index, straw yield. Application of $69 \mathrm{~kg} \mathrm{~N}^{-1}{ }^{-1} \mathrm{Y}$ resulted the highest plant height $(87 \mathrm{~cm})$, spike length $(6.1 \mathrm{~cm})$, biomass yields $\left(11363.8 \mathrm{~kg} \mathrm{ha}^{-1}\right)$, straw yields $\left(7708.5 \mathrm{~kg} \mathrm{ha}^{-1}\right)$ but at nil $\mathrm{N}$ application results the highest harvest index (36\%) [34]. Sole $\mathrm{N}$ rates and $\mathrm{N}$ timing had highly significant difference on durum wheat plant parameters and as a conclusion both sole applications of $92 \mathrm{~kg} \mathrm{ha}^{-1} \mathrm{~N}$ rate twice split application timing in the recommended form [32].

Effect of phosphorous fertilizer on yield and yield components of durum wheat

After nitrogen stress, phosphorus is the second most widely occurring nutrient deficiency in cereal systems around the world. Phosphorus is one of the most important essential macro elements for plants, which contributes in numerous vital function in plants like photosynthesis, energy transfer, respiration, cell division and seed formation [35].

Durum wheat (Triticum turgidum var. durum) and Triticale $(x$ Triticosecale Wittmack) genotypes can be classified as phosphorus efficient (higher yielding than other cultivars under low phosphorus supply) and/or responsive (higher yielding than other cultivars under high phosphorus supply) [36]. Many soils have large reserves of total phosphorus, but low levels of available phosphorus. Plants deficient in phosphorus are stunted and in contrast to those lacking nitrogen, are often dark green colors. Deficiency of P in wheat caused reduced tillering, reduced leaf area and increased susceptibility to number of diseases. 
Besides, maturity is often delayed in P deficient plants as compared to plants containing abundant phosphate. Plant $\mathrm{P}$ uptake is influenced by $\mathrm{P}$ supply, characteristics of the soil and $\mathrm{P}$ requirement of crop plants. When $P$ was withheld at early growth period of the plant, tillering and secondary root development was hindered. Early tillering was significantly higher and plants developed both root systems due to adequate $\mathrm{P}$ fertilization than only primary or adventitious roots under $\mathrm{P}$ deficient conditions [37]. phosphorous absorption by wheat begins in the seedling stages. In early stages of development, crop plants absorb phosphorous faster from fertilizer than from soil and hence a high proportion of the total $\mathrm{P}$ absorbed by young plants is derived from the fertilizer.

Therefore, Phosphorous fertilizer application at later stages of the crop may result in a greater P uptake but would have less effect on yield. On the contrary, supply of Pat heading stage in wheat was found to be adequate to produce maximum dry matter and grain yield [38]. Further, most of the phosphorus accumulated by cereal crops and grain legumes is contained in grains and is thus removed from the field at harvest.

Phosphorous fertilizer application significantly and positively influenced grain yield and number of tillers of wheat [33]. From research conducted on Nitosols of Central highlands of Ethiopia, statistically significant differences were not observed among yield of wheat for $\mathrm{P}$ fertilizer rates beyond $30 \mathrm{~kg} \mathrm{P} \mathrm{ha}^{-1}$, indicating that $P$ levels between 10 and $30 \mathrm{~kg} \mathrm{ha}^{-1}$ may be adequate, depending on soil P status. The response to the added phosphorus fertilizer, significant differences were observed in growth, yield, yield components, and phosphorus uptake among the wheat varieties [39].

Effect of sulfur fertilizer on yield and yield components of durum wheat

Sulfur plays many important roles in the growth and development of plants. A $2700 \mathrm{~kg} \mathrm{ha}^{-1}$ wheat crop contained $12 \mathrm{~kg} \mathrm{ha}^{-1}$ of $\mathrm{S}$ in the seed and straw, which was a very small quantity compared with that of nitrogen (N) $\left(2 \%-3 \%\right.$ or 54 to $\left.81 \mathrm{~kg} \mathrm{ha}^{-1}\right)$. Sulfur is an important component of two amino acids, cysteine and methionine, which are essential for protein formation. Sulfur also improves milling and baking quality of cereal crops; enhance oil content of oilseed crops; maintain winter hardiness and drought tolerance in plants; controls certain soil borne diseases and decreases fungal diseases in many crops helps in formation of glycosides that give characteristic odors and flavors to onion, garlic, and mustard; necessary for the formation of vitamins and synthesis of some hormones and glutathione; involves in redox reactions; improves tolerance to heavy metal toxicity; components of sulfolipids. It serves to enhance water solubility of organic compounds, which may be important in dealing with salinity stress [40].

Sulfur deficiency symptoms are similar to those of nitrogen. However, $\mathrm{N}$ deficiency symptoms first appear in the older leaves; generally while sulfur deficiency symptoms first appear in the younger leaves because $S$ is not easily translocated in the plant [41]. Sulfur-deficient plants lack vigor, are stunted, are pale green to yellow in color, and have elongated thin stems. Sulfur deficiency may delay maturity in grain crops.
Flaten described a comprehensive study which showed that analysis of grain samples for total S, N, and N: S ratio accurately predicted the concentration of $\mathrm{S}, \mathrm{N}$, and $\mathrm{N}: \mathrm{S}$ ratio in flour of Canada west red spring (CWRS) and durum wheat. Application of S fertilizer is likely to benefit the bread making quality of Canada west red spring (CWRS) wheat grown in western Canada, wherever soil S is marginal to deficient for wheat yield. Sulfur fertilization significantly increased grain S concentration at six of twelve sites. Loaf volume was significantly improved at two of seven sites, with four more sites demonstrating slight improvements, when $\mathrm{S}$ fertilizer was applied. Sulfur fertilization also improved dough extensibility at six of seven sites (four significantly). Finally, S fertilization resulted in occasional increases in grain yield for Canada west red spring (CWRS) wheat, where S concentrations in conventional SO4-S tests indicate adequate supplies of $\mathrm{S}$ in soil.

The main reasons for sulfur deficiency are low organic matter content of the soil; low mineralization rate of organic matter due to unfavorable soil environment; depletion of soil reserves due to intensive cultivation, use of high yielding cultivars that remove greater amounts of $S$ from soil. The application of sulfur free fertilizers; declining $S$ reserves in soil due to accelerated rate of soil erosion; use of high rates of nitrogen and potassium fertilizers, which require high rate of Sulfur. An environmental policy leading to reduce $\mathrm{SO}_{2}$ atmospheric emissions, the massive use of nitrogen and phosphorus fertilizers and the introduction of high yielding crop cultivars resulted in a decrease in the sulfur content in the soils. Several researches agree on the importance of sulfur as a limiting factor in wheat production and quality deterioration [42].

It has been predicted that greater areas will be sulfur deficient in the future in many parts of the world because of growing highyielding crop cultivars, use of S-free fertilizers. The high cost of chemical fertilizers, and implementation of air pollution control measures or environmental pollution concern. The worldwide trend toward the replacement of ammonium sulfate and single superphosphate with fertilizers such as urea, mono- and di-ammonium phosphates, and triple superphosphate, all of which are low in sulfur, seems certain to cause an increase in the incidence of sulfur deficiency and hence there is a need to apply fertilizer sulfur.

The principal sources of sulfur addition to soil are chemical amendments or fertilizers, farmyard manures, or crop residues. In addition, gaseous forms of hydrogen sulfide $\left(\mathrm{H}_{2} \mathrm{~S}\right)$ and sulfur dioxide $\left(\mathrm{SO}_{2}\right)$ are released to the atmosphere by the burning of fossil fuels and are deposited to the soil by rain. Sulfur dioxide when combined with water forms sulfuric acid $\left(\mathrm{H}_{2} \mathrm{SO}_{4}\right)$, and when this acid finds its way to soil, it is known as acid rain. Sulfur addition to the soil from atmospheric gases in the mid-western United States is reported to be in the range of about 10 to $20 \mathrm{~kg} \mathrm{ha}^{-1}$ per year [43]. Sulfur is also available to plants from some irrigation water sources. The important depletion sources of sulfur from soil is uptake by crop plants, loss through erosion, surface runoff, leaching and immobilization by soil microbial activities, and adsorption by soil colloids. 
Effect of boron fertilizer on yield and yield components of durum wheat

Boron (B) is an essential micronutrient for plants, and plant requirements for this nutrient are lower than the requirements for all other nutrients except molybdenum and copper. It is the only non-metal among the micronutrients and also the only micronutrient present over a wide $\mathrm{pH}$ range as a neutral molecule rather than an ion [44].

Boron uptake by plants is controlled by the B level in soil solution rather than the total $\mathrm{B}$ content in soil. Plants absorb boron in the form $\mathrm{H}_{3} \mathrm{BO}_{3}$, and it moves to plant root mainly by mass flow and diffusion. Uptake of $\mathrm{B}$ in crop plants is mainly determined by yield level. The decrease in B uptake at harvest was associated with translocation of this element to grain. Boron recovery under field conditions by annual crops is generally in the range of 5 to $15 \%$ the year of application, and for most annual crops, uptake of 100 to $200 \mathrm{~g} \mathrm{~B} \mathrm{ha}^{-1}$ of applied B could be expected to be sufficient [45].

In B-deficient soils, use of appropriate source is fundamental to improve crop yields and B use efficiency. Principal B carriers are boric acid, borax, or sodium tetraborates are commonly used fertilizers for correcting B deficiency in crop plants. Boron deficiency causes grain sterility in wheat (Rerkasem., et al. 1997). Reproductive growth, especially flowering, fruit and seed set are more sensitive to B deficiency than vegetative growth. The range between deficiency and toxicity of B is quite narrow and an application of B can be extremely toxic to plant at concentrations only slightly above the optimum rate [46].

The sterility problem in wheat as a consequence of B deficiency has been reported in different parts of the world. Boron deficiency causes the poor development of anthers and pollen, and the failure of pollen germination in wheat has been identified as male sterility, resulting in grain set failure, with losses of grain yield and quality. As a result of the general immobility of B in plants that is characteristic of most species, plants require a constant supply of B during all phases of plant growth. Even a short period of limitation in B availability can depress plant growth. If B deficiency occurs during critical reproductive stages, significant yield losses can be expected [47].

\section{Varieties differences on yield and quality parameters of} durum wheat

Comparative studies of wheat cultivars from different breeding eras revealed that improved varieties often out-yield old cultivars by at least $50 \%$ [48]. However, within a genotype, the correlation between grain yield and grain protein content can be either close to zero or negative, depending on the fertility level. wheat cultivars significantly differed in grain yield and most of yield related traits.

Genotype by nitrogen interactions for grain yield in winter wheat trials were reported by scientists. In their study of winter wheat grown without $\mathrm{N}$ or with $170 \mathrm{~kg} \mathrm{~N} \mathrm{ha}^{-1}$, they found that most of the interaction between varieties and $\mathrm{N}$ rate was accounted for by three of the 20 varieties involved. Two varieties introduced in the 1980s gave similar yields at the high $\mathrm{N}$ rate but one was lowyielding and the other high-yielding in the absence of fertilizer. The problem of low availability of $\mathrm{P}$ can be undertook by exploiting genetic variability existing within crop genotypes for their ability of absorption and utilization of mineral elements from a nutrient stress environment [49]. Considering differential behavior of varieties of a species in nutrients, particularly $\mathrm{P}$, wheat genotypes were screened at deficient and adequate phosphorus levels for growth and phosphorus utilization.

The study conducted in northern part of Ethiopia in four districts showed that of the variations among the varieties for all the agronomic traits, except for grain yield were recorded. The variation among the varieties for plant height was very high, ranging from 62.7 to $97.5 \mathrm{~cm}$. Of the varieties evaluated, Mosobo exhibited the highest plant height. Unlike Mosobo, Waha is categorized under semi dwarf; registering a plant height of $63 \mathrm{~cm}$. Variation for kernel boldness was considerably high ranging from 41.5 to $49.5 \mathrm{~g}$ at $12 \%$ moisture content. Interestingly, all the varieties evaluated were bold-kernelled and fulfilled the minimum acceptable kernel size (35 g at 14\% moisture content) to be certified for pasta processing [50].

\section{Effect of NPSB fertilizer on quality parameters of durum} wheat

Nitrogen application rate can have large direct effects on grain quality [51]. Furthermore, grain protein content was found to increase with the amount of applied nitrogen whether or not a yield increase resulted [52]. Nitrogen is important for protein formation; therefore, an adequate supply of $\mathrm{N}$ is a prerequisite for high protein yields. In addition to being of great importance nutritionally, grain protein plays a fundamental part in food processing, for instance, in the manufacture of bread, and pasta. It is known that nitrogen nutrition affects the wheat protein content and composition and directly influences the technological quality of wheat samples. High levels of nitrogen fertilizer can result in to higher protein content in wheat grains and increased grain yield under appropriate conditions within the given range [53]. However, in general, increasing $\mathrm{N}$ rates does not necessarily improve grain yield and quality unless tailored to crop requirements for a variety of conditions [54].

Application of $\mathrm{N}$ favors protein build-up in the grain over an increase of yield and thereby influences the bread-making quality of the resulting flour. In many cases, nitrogen fertilization is necessary and both rate and timing of $\mathrm{N}$ applications are important to attain desirable grain protein quantity. Accordingly, delaying soil $\mathrm{N}$ fertilization to around the time of second node formation is known to impact positively on grain protein content. Therefore, a farmer should analyze what production technology practices will impact better grain productivity, grain quality and consequently the profit on the wheat crop.

Differentiation of levels of $\mathrm{N}$-fertilization causes some changes in the quality of grain. Most often, it changes the 1000-grain weight, 
protein content and gluten. To a certain extent, the gluten index changed as well. Increase of $\mathrm{N}$-fertilization rate from 50 to $150 \mathrm{~kg}$ $\mathrm{ha}^{-1}$ caused an improvement of grain quality, in terms of protein content, wet gluten content and gluten index [55]. In general, high grain yield, optimum grain nitrogen content, protein yield and grain protein content in wheat can be associated with relatively high and balanced soil fertility regimes [56]. The kernel hardness is affected by both durum wheat variety and the rate of applied nitrogen fertilization. They also noted that the application of higher rate brought about a slight decrease of the typical value. This implies that kernel hardness was dependent on the level of nitrogen fertilization of plants [20].

The influence of fertilization on pigments content was assessed by [57]. They found out that higher nitrogen fertilization level lowered total carotenoids content in the grain. Vitreousness which is a physical characteristic of grain and affects largely milling quality was also influenced by $\mathrm{N}$ fertilization. In general, durum wheat owing to its unique properties such as high carotenoid pigments content, high vitreousness, hardness and gluten proteins composition makes suitable raw materials for the pasta industry.

However, in view of economic and environmental concerns, more efficient ways of fertilizing wheat crops with $\mathrm{N}$ should be investigated, since the encouragement of high $\mathrm{N}$ inputs to combine high yields with high quality increases may lead to the risk of nitrate leaching and $\mathrm{N}$ volatilization without necessarily giving a consistent benefit to the end user [51]. Therefore, optimum nitrogen fertilization is necessary to produce high yields of wheat and to increase the protein content and quality of the grain.

Phosphorus has long been known to be an essential element in the nutrition of plants. It plays key roles in cellular energy transfer, respiration, and photosynthesis. In addition, phosphorus plays an essential role in many physiological and biochemical processes and is an essential component of deoxyribonucleic acid (DNA) and ribonucleic acid (RNA).

Further, milling and baking quality of wheat appears to be closely associated with an optimum balance between sulfur and nitrogen, since sulfur is both a building block for proteins and enzymes and S-containing amino acids are important in forming the highquality glutenins and gliadins. The knowledge of sulfur nutrition effect on grain yield, quality and protein composition are limited in durum wheat (Triticum durum). A significant increase in grain protein content and sodium dodecyl sulfate (SDS) sedimentation Volume-test following sulfur fertilization, although no changes in rheological parameters (farinograph energy level, farinograph tolerance and viscoelasticity of cooked pasta) were observed, presumably due to non-limiting conditions for sulfur availability [42].

Nevertheless, several authors suggested S-fertilizer supply even in regions not deficient in soil S, especially under conditions of high $\mathrm{N}$, to ensure the synthesis of S-rich proteins and disulphide-bridge formation required for gluten [42]. Monomeric gliadins form only intra-chain disulphide bonds and contribute mainly to viscosity of dough, while polymeric glutens have both intra-chain and inter- change disulphide bonds and contribute mainly to dough elasticity, a decrease of dough extensibility related to a reduction of the disulphide groups, probably due to a lower concentration of sulfur in wheat grain.

The need of proper sulfur (S) fertilization of wheat on Sulfur deficient soils in Ethiopia was established in the sixties [58].

Boron is essential for germination of pollen grains; growth of pollen tubes; seed and cell wall formation; protein formation; important in the synthesis of nucleic acids and cytokinins; facilitates sugar translocation, improves seed germination and seed vigor. Boron is involved in $\mathrm{N}$ and $\mathrm{P}$ metabolism, in plants poorly supplied with $\mathrm{B}, \mathrm{NO}_{3}-\mathrm{N}$ accumulated in the roots, leaves, and stems, showing that $\mathrm{NO}_{3}$ - reduction and amino acid synthesis were inhibited. Boron is mainly associated with cell wall pectin, and physical characteristics of the growing cell wall were altered under B deficiency.

\section{Discussion}

Soil testing and plant analysis provide the best information concerning the native nutrient status of the soil and the nutrient requirement of the crop [59]. Therefore, the resultant values of these tests provide scientific basis for fertilizer recommendations for a specific nutrient element and crop on specific soil type.

Research continued from mid 1970s onwards and recommendations specific to some soil types and crops were made. However, fertilizer trials carried out between 1975 and 1990 were conducted on few research stations, and little effort was made to extrapolate the results to wider range of environments. The only exception was NFIU/ADD fertilizer trials which were conducted over wider geographical areas with presumption that $\mathrm{N}$ and $\mathrm{P}$ in that order are the only plant nutrients that limit crop growth (ADD/NFIU Joint working Paper No. 43, 1992).

NFIU made recommendation for different crops based on soil colors, soil types by region and showed profitability of fertilizer use in different crop and soil situation. It also suggested application of more $\mathrm{N}$ than P, i.e. 1:1 Urea and DAP application. Nevertheless, the NFIU trials were agronomic in nature and the soil test data gathered were of very limited value with regard to the development of soil test-crop yield response curves. As a result, translation of the yield data from multi location field trials into site specific rate of fertilizer recommendations was a problem. Since 1995, blanket fertilizer recommendation, $100 \mathrm{~kg}$ urea ha-1 (46-0-0) and $100 \mathrm{~kg}$ DAP ha-1 (18-46-0) was reinstated as sole fertilizer recommendation in the country despite criticisms. At this time, Agricultural Transformation Agency (ATA) collaborated with EtioSIS, made site specific blended fertilizer to maximize crop production through the country.

Thus, there is a need to pay more attention to fertilizer-useefficiency of the limited amounts that farmers can buy, instead of basing fertilizer recommendations on the face value of agronomic responses, which often suggests large requirements for inorganic fertilizers. The risk of a nutrient limiting crop yield must be balanced against cost and impact on the balance of nutrient levels in 
the soil. This call for site-specific recommendation that considers both the agronomic and environmental risks is to determine a rate of nutrient application that maximizes its beneficial use.

New fertilizer materials with value addition and micronutrients would be required to ensure balanced fertilizer use involving all or most of the nutrients required by crops. Balanced fertilization not only guarantees optimal crop production, better food quality and benefits for the growers, but is also the best solution for minimizing the risk of nutrient losses to the environment. Nutrients such as $\mathrm{Zn}, \mathrm{B}$, and S can often be included relatively economically in new fertilizer formula; when targeted to deficient soils, these nutrients can dramatically improve fertilizer-use efficiency and crop profitability.

Soil test based application of plant nutrient helps to realize higher response ratio and benefit: cost ratio as the nutrients are applied in proportion to the magnitude of the deficiency of a particular nutrient and correction of the nutrients imbalance in soil helps to harness the synergistic effects of balanced fertilization [17]. Location specific fertilizer recommendations are possible for soils of varying fertility, resource conditions of farmers and level of target yield conditions of similar soil classes and environment.

Unfortunately, in the past soil testing and related field experiments were often not completed, or they focused on only one or two nutrients while ignoring the others. Balanced fertilization must consider all essential plant nutrients because if any nutrient is deficient, it will affect both crop yield and quality, as well as use efficiency of other applied plant nutrients.

\section{Conclusion}

In general, wheat processing agro-industry is becoming more efficient and versatile, and therefore requires more specific quality characteristics to produce distinct flour and food types. Many of the cultivars have resulted in increased grain yield which are not always matched by quality improvements. Thus, combining grain yield with quality has become an important issue. Therefore, in order to ensure wheat cultivars possessing high productivity of specific quality attributes nutrient management practice is crucial.

\section{Conflicts of Interest}

The authors declare no conflict of interest.

\section{Bibliography}

1. Cooke RJ and Law JR. "Seed storage protein diversity in wheat varieties". Plant Variety Seeds 11 (1998): 159-167.

2. Efrem B., et al. "Durum wheat in Ethiopia: An old crop in an ancient land". Institute of Biodiversity Conservation and Research. Addis Ababa, Ethiopia (2000): 68.

3. CSA (Ethiopian Central Statistical Agency). "Agricultural sample survey Report on area and production for major crops". 1 (2017): 584 .
4. Kahrizi D., et al. "Heritability and genetic gain of some morph physiological variables of durum wheat (Triticum turgidum var. durum)". African Journal of Biotechnology 9.30 (2010): 4687-4691.

5. Badebo A., et al. Overview of durum wheat research in Ethiopia: Challenges and prospects Paper presented at the Proceedings of Borlaug Global Rust Initiative technical workshop, Cd. Obregon, Sonora, Mexico (2009).

6. Byerlee D and Moya P. "Impacts of international wheat breeding research in the developing world, 1966-1990". CIMMYT, Mexico, D.F (1993).

7. Gooding MJ., et al. "Effects of restricted water availability and increased temperature on the grain filling, drying and quality of winter" (2003).

8. Abiye Astatke., et al. "Participatory On-farm conservation tillage trial in Ethiopian highland Vertisol: The impact of potassium application on crop yield". Experimental Agriculture 40 (2003): 369-379.

9. EthioSIS (Ethiopian Soil Information System). Soil analysis report. Agricultural Transformation Agency (2013).

10. Arega Gashaw., et al. "Varietal Differences and Effect of Nitrogen Fertilization on Durum Wheat (Triticum turgidum var. durum) Grain Yield and Pasta Making Quality Trial" (2013).

11. Pena RJ., et al. "Quality (end-use) improvement in wheat: compositional, genetic, and environmental factors". In: A. S. Basra, and L. S. Randhawa ( eds). Quality Improvement in Field Crops, Food Products Press, Binghampton, NY (2002): 1-39.

12. International Wheat Council. World production of durum wheat. The Council, London (1991).

13. Peterson CJ., et al. "Baking quality of hard red winter wheat: Response of geno-types to environment in the Great Plains". Euphytica 100 (1998): 157-162.

14. Bryan G J., et al. "A PCR-based Method for the Detection of Hexaploid Bread Wheat Adulteration of Durum Wheat and Pasta". Journal of Cereal Science 28 (1998): 135-145.

15. Ammar K., et al. "Bread making quality of selected durum wheat genotypes and its relationship with high molecular weight glutenin subunits allelic variation and gluten protein composition". Cereal Chemistry 77 (2000): 230-236.

16. Marchylo BA., et al. "Relationships among bread-making quality, gluten strength, physical dough properties, and pasta cooking quality for some Canadian durum wheat genotypes". Canadian Journal of Plant Science 81 (2001): 611-620.

17. Rao BN., et al. "Baking quality of emmer-derived durum wheat breeding lines”. Journal of Cereal Science 51 (2010): 299-304.

18. Tekalign Mamo., et al. "Soil fertility and plant nutrition research on tef in Ethiopia". In narrowing the rift. Tef research and development. Proceedings of the International Workshop on Tef Genetics and Improvement (2010): 191-200. 
19. Sinclair TR and Rufty TW. "Nitrogen and water resources commonly limit crop yield increases, not necessarily plant genetics". Global Food Security 1 (2002): 94-98.

20. Makowska A., et al. "Effect of nitrogen fertilization of durum wheat varieties on some characteristics important for pasta production". Acta Science Pol., Technologia aimentarai 7.1 (2008): 29-39.

21. Asnakew W., et al. "Soil fertility management studies on wheat in Ethiopia” (1991): 137-170.

22. Borghi B., et al. "Effects of Mediterranean climate on wheat bread-making quality". European Journal of Agronomy 6 (1997): 145-154.

23. Guarda G., et al. "Grain yield, nitrogen-use efficiency and baking quality of old and modern Italian bread-wheat cultivars grown at different nitrogen levels". European Journal of Agronomy 21 (2004): 181-192.

24. Warraich EA., et al. "Effect of nitrogen on source-sink relationship in wheat". International Journal of Agriculture and Biology 4 (2002): 300-302.

25. Zahran M., et al. "Effect of sowing date, seeding rate and nitrogen level on wheat production: 1- growth and growth attributes". First Annual Conference. September 1-3, NRC, Egypt (1997).

26. Alam SM., et al. "Effect of boron application with or without zinc on the yield of wheat". Pakistan Journal of Soil Science 18 (2007): 95-98.

27. Sobh MM., et al. "Response of wheat to nitrogen and potassium application in a salt affected soil". Journal of Product and Development 5.1 (2000): 83-98.

28. Briggs KG. "Spatial variation in seed size and seed set on spikes of some Canadian wheat cultivars". Canadian Journal of Plant Science 72 (1991): 247-249.

29. Behera UK., et al. "Influence of planting dates and nitrogen levels on yield and quality of durum wheat (Triticum durum)". Indian Journal of Agricultural Science 70 (2000): 434-436.

30. Zebrath BJ and Sheard RW. "Influence of rate and timing of nitrogen fertilization on yield and quality of hard red winter wheat in Ontario". Canadian Journal of Plant Science 72 (1992): 13-19.

31. Raun, WR and Johnson GV. "Soil- plant buffering of inorganic nitrogen in continuous winter wheat". Agronomy Journal 87 (1995): 827-834.

32. Tilahun Chibsa., et al. "Effect of rate and time of nitrogen fertilizer application on durum wheat (Triticum turgidum Var L. durum) grown on Vertisols of Bale highlands, south eastern Ethiopia”. American Journal of Research Communication 5.1 (2017): 39-56

33. Damene Darota. "Yield response of bread wheat (Triticum aestivumL.) to applied levels of $\mathrm{N}$ and $\mathrm{P}$ fertilizers on Nitosol of Dawro Zone, South Western Ethiopia”. MSc thesis School of Graduate Studies, Alemaya University, Ethiopia (2013).
34. Abdo Woyema., et al. "Effect of different nitrogen fertilizer rates on yield and yield related traits for seven durum wheat (Triticum turgidum L. var Durum) cultivars grown at Sinana, South Eastern Ethiopia”. African Journal of Food, Agriculture, Nutrition and Development 12.3 (2012): 6079-6094.

35. Mengel and Kirkby E.A. "Principles of Plant Nutrition". 5th Edition. Kluwer Academic Publishers, Dordrecht, Boston, London (2001): 849.

36. Gerloff S. "Plant efficiencies in the use of N, P and K. In: Plant adaptation to mineral stress in problem soils. M.J. Wright (ed.) Cornell Univ. Press: New York. (1977): 161-174.

37. Strongh WM and Soper RJ. "Phosphrous Utilization by flax, wheat, rape, and buckwheat from a band or pellet like application I". Reactions zone root proliferation (1974).

38. Singh NT., et al. "Influence of different levels of irrigation and nitrogen on yield and nutrient uptake by wheat". Agronomy Journal 71 (1979): 401-404.

39. Abdi Mussa Ahmed. "Response of Bread Wheat (Triticum aestivum L.) Varieties to the Application of Mineral NP Fertilizers and Farmyard Manure in Jijiga Plain, Eastern Ethiopia”. MSc thesis, Haramaya University (2016).

40. Clarkson DT and Hanson JB. "The mineral nutrition of higher plants". Annual Review of Plant Physiology 31 (1980): 239298.

41. Flaten Don. "Effects of Sulfur Nutrition on Grain Quality of Wheat". Manitoba Agriculture, Food and Rural Initiatives (2004).

42. Lerner SE., et al. "N-and S-fertiliser effects on grain composition, industrial quality and end-use in durum wheat". Journal of Cereal Science 44 (2006): 2-11.

43. Barber SA. "Soil nutrient bioavailability: A mechanistic approach". New York: John Wiley and Sons (1995).

44. Epstein E and Bloom AJ. Mineral nutrition of plants: Principles and perspectives, 2nd edition. Sunderlands, MA: Sinauer Associates (2005).

45. Shorrocks VM. "The occurrence and correction of boron deficiency". Plant Soil 193 (1997): 121-148.

46. Gupta, U.C., Jame, Y.W., Cambell, C.A., Leyshon, A.J. and Nicholaichuk, W. (1985).

47. Brown $\mathrm{PH}$ and $\mathrm{Hu} \mathrm{H}$. "Does Boron play only a structural role in the growing tissues of higher plants?" Plant and Soil 196 (1997): 211-215.

48. Slafer GA., et al. "Increases in grain yield in bread wheat from breeding and associated physiological changes". European Journal of Agronomy 30 (1994): 1-68.

49. Clark RB and Duncun RR. "Improvement of plant mineral nutrition through breeding". Field Crop Research 27 (1991): 219-246.

50. Abaye A., et al. "Winter Durum Wheat: Do We Have All the Answers?" Virginia Cooperative Extension (2009). 
51. Gooding MJ and Davies WP. "Wheat production and utilization: systems, quality and the environment". Wallingford $\mathrm{CAB}$ International. UK (1997).

52. Laubscher EW. "Nitrogen application, protein content and quality of wheat. Paper presented on award of FSSA Silver Medal". Fertilizer Society of South Africa Journal 2 (1981): 4147.

53. Kirda, C., et al. "Yield response and N-fertilizer recovery of rainfed heat growing in the Mediterranean region". Field Crops Research 71 (2001): 113-122.

54. David C. "Nitrogen management in organic farming: nutrient requirement and fertilization efficiency of winter wheat". in: proceeding of the 11th world fertilizer congress of CIEC Gent September 7-13, Gent University and international scientific center of fertilizers (1997): 647-660.

55. Borkowska H., et al. "Yield quantity and quality of some varieties of spring wheat in dependence of nitrogen fertilization". Annales UMCS, Section E 57 (2002): 99-103.

56. Araus JL., et al. "Recent tools for the screening of physiological traits determining yield". In: M. P. Reynolds, J. I. Ortiz-Monasterio and Mc Nab (eds). Application of physiology in wheat breeding. Mexico, D.F (2001)

57. Chwil S. "Estimation of results of winter wheat nitrogen fertilization". Fragmenta Agronomica 1 (2004): 19-28.

58. Bentley C F., et al. "Fertilizers and the nutritive value of wheat grown on a sulfur-deficient grey wooded soil". Canada Journal of Plant Science 40 (1960): 146-155.

59. Ryan J., et al. "Soil and plant analysis laboratory manual second edition". ICARDA, Aleppo, Syria (2001): 172.

\section{Volume 3 Issue 11 November 2019}

(C) All rights are reserved by Melaku Tafese Awulachew. 